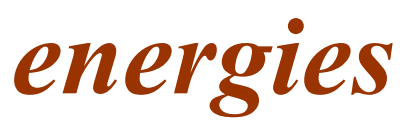

ISSN 1996-1073

www.mdpi.com/journal/energies

Article

\title{
Efficacy and Efficiency of Italian Energy Policy: The Case of PV Systems in Greenhouse Farms
}

\section{Filippo Sgroi *, Salvatore Tudisca, Anna Maria Di Trapani, Riccardo Testa and Riccardo Squatrito}

Department of Agricultural and Forest Sciences, University of Palermo, Viale delle Scienze, 90128 Palermo, Italy; E-Mails: salvatore.tudisca@unipa.it (S.T.);

annamaria.ditrapani@nipa.it (A.M.D.T.); riccardo.testa@unipa.it (R.T.);

riccardo.squatrito@unipa.it (R.S.)

* Author to whom correspondence should be addressed; E-Mail: filippo.sgroi@unipa.it;

Tel.: +39-091-238-966-15; Fax: +39-091-484-035.

Received: 14 May 2014; in revised form: 11 June 2014 / Accepted: 17 June 2014 /

Published: 24 June 2014

\begin{abstract}
The production of energy from renewable sources is a form of energy production that has less impact on the environment than the traditional one. For the farmer this new form of production represents an opportunity, especially for the economic benefits that can produce, both in terms of the incentives provided by the public operator and for higher revenues, deriving from the sale of energy back to the grid and/or the savings generated by self-consumed energy, that help to increase the farmer's income. In this paper, we analyzed a case study of a farm that has realized a grid-connected photovoltaic (PV) system on a greenhouse. In particular, firstly the farm profitability has been estimated and subsequently, in order to assess the efficiency of the energy policy adopted by the Second Conto Energia in Italy, the minimum incentive tariff at which the entrepreneur has an economic advantage to realize a PV system has been determined. Results show that PV system relegates to a marginal role the cultivation of agricultural products compared to energy production and that government PV remuneration policies far outweigh the minimum threshold that makes the investment advantageous.
\end{abstract}

Keywords: incentive tariffs; profitability; breakeven point 


\section{Introduction}

In recent years, legislators have paid particular attention to the multifunctional role of the farm. The legislator's goal is to increase the farm competitiveness through diversification of income opportunities. Among these we can mention the energy production from renewable sources, agrotourism and other activities involved with farming [1]. Farmers, in fact, in order to compete on the global market, have to be able to change their entrepreneurial strategies and improve their economic performance, thus incorporating "added value" [2,3]. Nevertheless, one should not forget that the farmer is required to produce agricultural products and thus the production of goods and services related to agriculture must be considered to supplements to his income or a way of reducing production costs $[4,5]$.

Renewable energy sources such as hydropower, biomass, geothermal, wind and solar represent a viable alternative to traditional fossil fuels both for the benefits in terms of reduced impact on the environment and for their ability to be renewable and not subject to depletion [6,7]. The green energy, moreover, by limiting the consumption of fossil fuels and reducing the release of greenhouse gases into the atmosphere, contributes to the achievement of targets set by the Kyoto Protocol, avoiding sanctions for signatory States in case of defaults [8].

However, even though the international agreements have aimed at reducing human pressure on the environment, the lack of unity of intents, originated from merely internal interests of some of the world powers involved, has not allowed charting a course that is fully shared yet.

The purpose of environmental sustainability of productive processes is to preserve the environment overthe course of time so that future generations can benefit to the same extent of natural resources.

In this context a key role is played by agriculture that, through its activities and peculiarities, lends itself to the achievement of these objectives in environmental, economic and social terms [9].

The production of electricity by PV panels is a productive process with an environmental impact near to zero, since it benefits from the sunlight for operation, making it the renewable energy source par excellence. In a word, PV technologies are proved to be sustainable and environmental-friendly regarding the measured Energy Pay-Back Time (EPBT) and Greenhouse Gas (GHG) emission rates [10]. This peculiarity makes PV energy a viable alternative to fossil fuel energy sources such as coal and oil.

The development of the PV sector has contributed to the expansion of the renewable energy sector, mainly thanks to the advantageous subsidy policies available in various countries [11]. This has attracted the interest of many small investors and especially of large financial groups that have decided to invest in solar energy [12], assuming a leading role in European energy policies [13].

Over the last years in Italy an exponential growth of PV industry has occurred, involving also the primary sector through the realization of PV systems on ground or buildings that have allowed farmers to diversify their income and made farm increasingly sustainable and multifunctional [14]. In this way, Italy has became the second country in Europe in terms of cumulative installed capacity behind Germany, and the first relative to 2011 [15]. The success of the PV sector is mainly attributable to the substantial incentives granted by the state and it has created also positive effects in terms of employment, creating more than 100,000 jobs in Italy from 2002 to 2010, of which about 20,000 represent direct employees with an average age less than 35 years [16]. 
An additional benefit related to the energy production from solar panels is the contribution for the achievement of the objectives (better known as the "20-20-20" targets) set by the European Union to promote energy from renewable sources, which provided for Italy to reach in 2020 a share of $17 \%$ of energy from renewable sources in the consumed energy mix [17].

Among the various possible PV system typologies, the placement of PV modules on greenhouses avoids the contested debate about land use because, unlike ground systems, it does not subtract from surfaces usable for the cultivation of agricultural products.

The installation of PV systems on agricultural soils (ground mounting), in fact, does not seem coherent with the need to promote activities aimed at energy production which are expression of agricultural multifunctionality. The installation of this type of PV systems is not only in competition with the agricultural activities for land occupation, but subtracts from it for very long periods (at least twenty years) and, what is worse, compromises its fertility, making future recovery for agricultural purposes particularly difficult [18]. For this reason in Italy the access to incentives for PV systems with modules located on agricultural surfaces is no longer allowed [19].

In this case the PV panels installed on greenhouse can represent a solution to the problem, encouraging the development of more transparent solar panels and the selection of suitable PV plants for this particular production system, characterized by a poorly lit environment [20]. The large availability of surfaces ensured by greenhouses and farm buildings can be exploited by farmers while respecting the environmental and landscape equilibrium of land for the benefit of a new environmentally sustainable image of their agricultural activity, reducing energy demand [21,22] and contributing to sustainable management of natural resources as well as other renewable sources $[23,24]$. Besides, the political support of PV modules on greenhouse and/or farm buildings would contribute to promote the development of a region, creating new job opportunities and supporting entrepreneurs' income [25].

In order to better understand the causes of the diffusion of PV systems in Italy, the aim of this paper has been to evaluate the efficacy and efficiency of Italian energy policy. Efficacy could be defined as the ability to achieve planned objectives, regardless of allocated resources. Efficiency, conversely, refers to use of factors in productive processes and corresponds to the ratio between obtained production and allocated resources [26,27]. Subsequently a certain economic policy could be efficacious but not efficient, as in order to achieve the planned objectives it may have used more resources respect to the appropriate costs to realize it.

As regards the efficacy of Italian energy policy, the latest available data on development of the Italian PV sector have been taken into consideration in order to highlight its sudden development in the last years. Subsequently, in order to evaluate the efficiency of Italian energy policy, first the profitability of a representative farm located in Sicilian northwestern coast that produces electricity by PV panels on greenhouse installed during the Second Conto Energia has been estimated. Then, the minimum incentive tariff starting from which the farmer has an economic advantage to realize the PV investment has been determined in order to assess if the PV incentive was reasonable compared to the goal of Second Conto Energia. 


\section{Photovoltaic Remuneration Policies in Italy}

The widespread diffusion of PV systems within the Italian territory coincides with the approval of regulatory interventions aimed at incentivizing the electricity produced by PV panels, better known as Conto Energia, today is its 5th edited version. The Conto Energia is a feed-in scheme aimed at the promotion of energy production from PV systems accordance with Directive 2001/77/EC [28], implemented in Italy by D.L. 29/12/2003 No. 387 [29]. This feed-in scheme incentivizes the electricity produced in Italy by grid connected PV systems, with a nominal capacity greater than $1 \mathrm{~kW}$.

The incentive depends on the size of the PV system, technology, PV type and other factors (origin of the materials used for its construction, replacement of roofs/covers from which Eternit or asbestos has been completely removed, etc.). Individuals, organizations, public institutions, non-commercial entities, and owners of single or multiple housing units are eligible for the Conto Energia.

The Conto Energia, which grants incentive tariffs for energy produced by PV systems over a period of 20 years, has became operational in 2005 with the entry into force of its first version [30,31], that has introduced the revenue grants for electricity production, replacing the previous government financing system based on non-refundable grants allocated to PV systems.

With the Second Conto Energia [32], the Italian Ministry of Economic Development has set new standards to incentivize electricity production by PV systems commissioned by 31 December 2010. Among the main changes introduced by the Second Conto Energia there are the application of the incentive tariff on all produced energy and not merely on that is self-consumed, the simplification of bureaucratic procedures to obtain public grants and the tariff differentiation based on the type of architectural integration, as well as the PV system size.

In 2010 the Third Conto Energia [33] entered into force, applicable to PV systems commissioned between 1 January 2011 and 31 May 2011. It has defined the following system categories: (a) PV plants (divided into "PV systems on buildings" or "other PV systems"); (b) integrated PV plants with innovative features; (c) concentrating PV plants; (d) PV plants with technological innovations.

Afterwards it was established that the tariffs provided for Second Conto Energia could be granted to all investors that have completed the installation of PV systems by 31 December 2010 that came into operation by 30 June 2011 [34]. This decision has effectively extended until 30 June 2011 the Second Conto Energia, originally intended to run out at the end of 2010 for the entry into force of the Third Conto Energia.

The Fourth Conto Energia [35] has been published on 12 May 2011. It set out the mechanism of incentives for the electricity production from PV systems commissioned between 1 June 2011 and 31 December 2016.

All four of these regulatory interventions include feed-in tariffs as the type of incentive policy to encourage PV installations. This kind of tariff provides a fixed-price contract per $\mathrm{kWh}$ of generated energy for a twenty years period, to which any revenue from the electricity fed into the grid has to be added, subject to price fluctuations. Alternatively the electricity fed into the grid can be economically offset with the value of electricity withdrawn from the grid service (net metering). The major benefit of feed-in tariffs is that private independent producers receive a long-term minimum guaranteed price for the electricity they generate. 
This kind of incentive tariff is common in many EU countries (Germany, Austria, Czech Republic, Spain, France, the Netherlands, Portugal and Switzerland) and according to some studies [36-38] appears to be the most effective method to increase the diffusion of the energy generation systems, as it ensures a long-term investment with a low risk for investors, regardless any future price fluctuations in the energy market.

Over the years, with the succession of feed-in schemes, there has been a sudden expansion of the PV industry that has led to a reduction of price for the PV systems, which has decreased by $50 \%$ in Europe during five years [39], and to an increase of the objectives set by the legislators. In fact, despite the public authority had set only a short time ago a target of $8 \mathrm{GW}$ at the national level by the end of 2020, the legislature raised the ceiling to $23 \mathrm{GW}$ of installed capacity from PV panels to be achieved by 2016 [40].

For these reasons the legislature has tried to find a solution to balance the level of public support with the costs of technologies, providing stability and certainty to the market. To this end tariffs have been reduced over a few years with a succession of different regulatory interventions, reflecting inadequate forecasts of PV industry development and potential [30-35]. Despite the uncertainty of the public action, in contrast to the findings of some studies [41], the development of PV industry in Italy has not experienced significant breaks.

The last feed-in scheme adopted by Italian government has been the Fifth Conto Energia [42]; it entered into force on 27 August 2012, after the annual indicative cumulative cost of incentives has reached 6 billion euro. Incentive tariffs of this feed-in scheme are granted to PV plants (divided by type of installation), building integrated PV plants with innovative features and concentrating PV plants. Unlike the previous support schemes, the Fifth Conto Energia grants an all-inclusive feed-in tariff to the share of net electricity injected into the grid and a premium tariff to the share of net electricity consumed onsite. The Fifth Conto Energia ceased to have effect on 6 July 2013, after reaching an indicative cumulative cost of the incentives provided of 6.7 billion euro per year.

\section{Growth of Installed PV Capacity in Italy}

Analyzing the electricity produced by PV plants, in Italy $65 \%$ of the installed capacity is allocated to the industrial sector, followed by the agriculture and the tertiary (13\% for both), while the domestic sector absorbs $9 \%$ of the produced energy [43]. Considering the capacity by type of site, in Italy $49 \%$ of the PV systems is placed on ground, $41 \%$ on buildings, and $6 \%$ on greenhouses or roofs/covers and the remaining part is on other sites. PV plants installed on buildings are prevalent in the northern regions whereas in south/central ones a preponderance of ground PV systems has been observed.

At the national level, $70 \%$ of installed capacity derives from multicrystalline silicon panels, the prevalent material in all regions, followed by monocrystalline silicon $(23 \%)$ while the remaining part is originated from thin film or other materials. According to data provided by the Gestore dei Servizi Energetici (GSE) [44] in Italy, during Conto Energia, 470,360 PV systems have been realized, which correspond to an installed capacity of $16,140,534 \mathrm{~kW}$ (Table 1$)$. 
Table 1. Evolution of Italian PV systems.

\begin{tabular}{|c|c|c|c|c|c|c|c|c|}
\hline \multirow[b]{2}{*}{ Regions } & \multicolumn{6}{|c|}{ Installed capacity $(\mathrm{kW})$} & \multicolumn{2}{|c|}{ Plants } \\
\hline & $\begin{array}{c}1 \text { st } \\
\text { Conto } \\
\text { Energia }\end{array}$ & $\begin{array}{c}\text { 2nd } \\
\text { Conto } \\
\text { Energia }\end{array}$ & $\begin{array}{c}\text { 3th } \\
\text { Conto } \\
\text { Energia }\end{array}$ & $\begin{array}{c}\text { 4th } \\
\text { Conto } \\
\text { Energia } \\
\end{array}$ & $\begin{array}{c}\text { 5th } \\
\text { Conto } \\
\text { Energia }\end{array}$ & Total & Num. & $\begin{array}{c}\text { Average } \\
\text { size }(k W)\end{array}$ \\
\hline Apulia & 26,331 & $1,273,878$ & 182,640 & 909,155 & 34,215 & $2,426,219$ & 33,039 & 73 \\
\hline Lombardy & 7,753 & 757,342 & 151,593 & 841,364 & 30,194 & $1,788,246$ & 67,394 & 27 \\
\hline Emilia R. & 14,055 & 678,493 & 151,951 & 707,325 & 29,803 & $1,581,627$ & 44,219 & 36 \\
\hline Veneto & 7,168 & 690,346 & 105,001 & 631,458 & 29,717 & $1,463,690$ & 63,997 & 23 \\
\hline Piedmont & 6,394 & 603,242 & 124,336 & 595,611 & 28,558 & $1,358,141$ & 33,596 & 40 \\
\hline Sicily & 9,682 & 375,005 & 117,059 & 535,119 & 62,004 & $1,098,869$ & 31,341 & 35 \\
\hline Lazio & 7,696 & 410,864 & 155,777 & 440,743 & 33,907 & $1,048,987$ & 26,252 & 40 \\
\hline Marche & 9,713 & 423,848 & 123,048 & 396,533 & 15,601 & 968,743 & 16,918 & 57 \\
\hline Tuscany & 8,028 & 247,459 & 72,946 & 283,218 & 17,340 & 628,991 & 24,399 & 26 \\
\hline Abruzzo & 3,960 & 201,284 & 57,557 & 315,974 & 14,923 & 593,698 & 11,708 & 51 \\
\hline Sardinia & 6,722 & 176,745 & 61,483 & 288,170 & 14,741 & 547,861 & 21,920 & 25 \\
\hline Campania & 7,778 & 164,794 & 62,260 & 280,250 & 17,773 & 532,855 & 16,062 & 33 \\
\hline Umbria & 5,722 & 165,028 & 51,547 & 183,879 & 3,913 & 410,089 & 11,258 & 36 \\
\hline Friuli V. G. & 2,209 & 167,958 & 39,013 & 175,521 & 11,918 & 396,619 & 22,193 & 18 \\
\hline Trentino A.A. & 11,108 & 202,591 & 32,113 & 116,893 & 1,728 & 364,433 & 18,155 & 20 \\
\hline Calabria & 10,738 & 104,881 & 26,773 & 199,441 & 20,156 & 361,989 & 14,091 & 26 \\
\hline Basilicata & 16,955 & 83,821 & 24,490 & 166,651 & 36,727 & 328,644 & 5,483 & 60 \\
\hline Molise & 540 & 40,645 & 16,862 & 91,112 & 1,322 & 150,481 & 2,528 & 60 \\
\hline Liguria & 833 & 32,746 & 4,815 & 33,107 & 1,184 & 72,685 & 4,298 & 17 \\
\hline Aosta Valley & 46 & 6,767 & 1,927 & 8,322 & 605 & 17,667 & 1,509 & 12 \\
\hline Italy & 163,431 & $6,807,737$ & $1,563,191$ & $7,199,846$ & 406,329 & $16,140,534$ & 470,360 & 34 \\
\hline
\end{tabular}

Taking into account the evolution of installed capacity in Italy, the First Conto Energia was characterized by a capacity of $163,431 \mathrm{~kW}$. This low value is not so much due to awareness among investors of the high returns on investment, but rather to the fact that the incentives were granted only to PV systems that only produced electricity for self-consumption.

The PV sector, in fact, has reached full achievement with the Second Conto Energia, through which a total capacity equal to $6,807,737 \mathrm{~kW}$ has been installed. The Third Conto Energia has been characterized by an installed capacity of 1,563,191 kW, while the Fourth Conto Energia has reached $7,199,846 \mathrm{~kW}$. The decrease in the Third Conto Energia is essentially attributable to its short implementation period, which allowed the installation of an exiguous number of PV plants. The Fifth Conto Energia, finally, having entered into force for a few months, denotes an installed capacity of just $406,329 \mathrm{~kW}$.

From the data analysis it appears evident that, starting from the First Conto Energia, despite the continuous reduction applied to PV incentives, in Italy there has been a continuous development of the PV industry, showing how this type of investment still appears to be highly remunerative for investors [45] and highlighting a high efficacy of the energy policy. The diffusion of the renewable energies is also evidenced by the funding commitments from banks within the sector that in Italy, in the period between 2007 and 2011, are estimated at over 20 billion euro [46]. 
Considering the national diffusion, Apulia is the first region for installed capacity $(2,426,219 \mathrm{~kW})$, representing $15.0 \%$ of the Italian total, followed by Lombardy (11.1\%), Emilia Romagna (9.8\%), Veneto $(9.1 \%)$ and Piedmont (8.4\%).

Furthermore, Apulia has been the first region for installed capacity per Conto Energia, exceeded only by Sicily and Basilicata in Fifth Conto Energia, highlighting the importance of the PV sector since 2005 when feed-in schemes entered into force.

Taking into consideration the number of PV systems, data show that Lombardy is the main region with a value equal to 67,394 installed plants, followed by Veneto $(63,997)$, Emilia Romagna $(44,219)$, Piedmont $(33,596)$ and Apulia $(33,039)$.

This means that Apulian leadership, in terms of installed capacity, is due essentially to the high average size of PV systems $(73 \mathrm{~kW})$, far higher than the Italian average size (34 kW). In Apulia, in fact, ground-mounted PV systems are especially abundant.

With regard to Sicily, the $31,341 \mathrm{PV}$ systems with an average size of $35 \mathrm{~kW}$, represent $6.8 \%$ of the national installed capacity $(1,098,869 \mathrm{~kW})$, placing it only in sixth place, behind regions with an significantly lower average annual solar radiation, which corresponds to a smaller amount of energy produced at the same level of installed capacity.

In Sicily $60 \%$ of the installed capacity is attributable to PV plants installed on ground, followed by installations on buildings (24\%). The PV systems installed on greenhouses and/or roofs/covers constitute $12 \%$ of the Sicilian capacity, generating an electricity production second only to that found in Sardinia. However it should be noted that Sicily, in recent years, has increased its participation at the national level in terms of installed capacity per feed-in scheme, passing from $5.9 \%$ of First Conto Energia to $15.3 \%$ of Fifth Conto Energia (Table 2).

Table 2. Sicilian incidence of PV installed capacity.

\begin{tabular}{cccccc}
\hline \multirow{2}{*}{ Items } & \multicolumn{5}{c}{ Installed capacity (kW) } \\
\cline { 2 - 6 } & 1st Conto & 2nd Conto & 3th Conto & 4th Conto & 5th Conto \\
& Energia & Energia & Energia & Energia & Energia \\
\hline Sicily (A) & 9,682 & 375,005 & 117,059 & 535,119 & 62,004 \\
Italy (B) & 163,431 & $6,807,737$ & $1,563,191$ & $7,199,846$ & 406,329 \\
A/B & $5.9 \%$ & $5.5 \%$ & $7.5 \%$ & $7.4 \%$ & $15.3 \%$ \\
\hline
\end{tabular}

These data can be correlated to favorable climatic conditions of the island [47-50] that, facilitating the production of energy from PV systems, permit to mitigate the lower revenues due to the gradual reduction of the incentive tariff granted for the amount of generated electricity.

\section{Case Study}

The analyzed case study concerns a small farm (equal to $1.50 \mathrm{ha}$ ) managed directly by the farmer and his family, located in the Sicilian northwestern coast, that has realized in 2010 a PV system on greenhouses during the Second Conto Energia. Considering that the collected data in this research respond only to economic purposes rather than probabilistic and statistical others [51-53], we have chosen to analyze a representative Sicilian greenhouse farm that invested in PV sector, trying to provide some indications about Italian energy policy on renewables. 
The investment has involved the construction of six lean-to greenhouses that occupy one third of the farm surface $(0.50 \mathrm{ha})$. The remaining part of the surface $(1.00 \mathrm{ha})$ is destined to a crop rotation between tomato (spring-summer species) and cauliflower (autumn-winter species). The species cultivated in greenhouses is white asparagus, which is well adapted to the poorly light conditions caused by the solar panels.

The greenhouses have a length of $50 \mathrm{~m}$ and a width of $8 \mathrm{~m}$; the lean-to greenhouses have optimum slope and azimuth. Since at the time of the investment realization there was no restriction on the coverage of greenhouses with solar panels, each slope has been completely covered by solar panels and it generates a capacity of $50 \mathrm{~kW}$ (about $8 \mathrm{~m}^{2} \cdot \mathrm{kW}^{-1}$ ). Overall, therefore, the installed capacity on the six greenhouses is equal to $300 \mathrm{~kW}$ (Figure 1).

Figure 1. Case study.

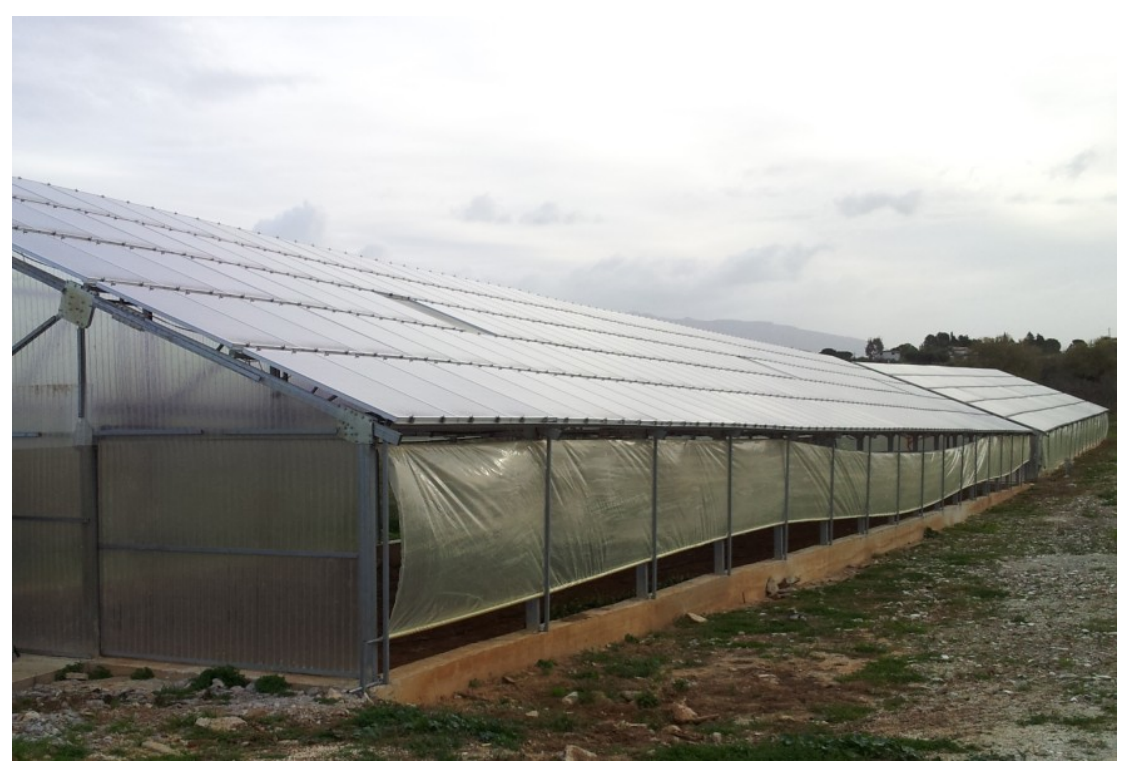

For the realization of the PV system multicrystalline silicon panels have been used, a less expensive material than monocrystalline ones, because of the simpler manufacturing process required, even if slightly less efficient [54].

The investment has required a total expenditure of $€ 1,170,000$, of which $€ 120,000$ come from the entrepreneur's funds and $€ 1,050,000$ were financed through a bank loan for a depreciation period of twenty years at an annual interest rate of $3.65 \%$. The entrepreneur's capital has been used for the construction of the six greenhouses, while the bank loan has financed the purchase and the installation of PV panels, equal to $3500 € \cdot \mathrm{kW}^{-1}$.

For the purpose of energy production, an electricity production of $1500 \mathrm{kWh} \cdot \mathrm{kW}^{-1} \cdot \mathrm{year}^{-1}$ it has been considered [55]; the annual PV electricity yield generated by the system is assumed to decrease every year by $0.8 \%[56,57]$.

In this way the analyzed PV system generates an annual average electricity production of $417,387.19 \mathrm{kWh}$. This average annual value derives from the sum of total electricity production during the twenty years (life cycle of PV system), considering the annual decrease rate on electricity yield. 


\section{Methodology}

In order to assess the profitability of the surveyed case study the farm profit, through the economic balance of the farm has been determined [58-60]. Since the case study concerned a farm that, despite the installation of solar panels, continues to produce agricultural products and that the energy produced is accounted as an activity related to agriculture, unlike other studies [61-63], for the profit determination we have considered costs and revenues deriving from both the PV system and agricultural activity, analyzing the farm as a whole. Revenues related to the agricultural activity have been calculated by multiplying the production of the three crops cultivated in the farm for their sale prices referred to 2012/2013 crop year.

For the calculation of the electricity production revenues, the average annual energy production of the plant during the incentive period (twenty years) has been considered, considering a tariff equal to $0.422 € \cdot \mathrm{kWh}^{-1}$ (provided for Second Conto Energia) and an average sale price of electricity generated amounting to $0.10 € \cdot \mathrm{kWh}^{-1}$, according to GSE data [64].

In our analysis we took into consideration only economic costs but not social and environmental ones as well as in other studies [65,66], because the aim of this paper was to evaluate the goals of PV Italian energy policy, according to which the tariff had to ensure a fair remuneration for investment and operational costs.

The economic farm costs have been divided into materials and services coming from outside the farm regarding productive factors which have a rapid financial replenishment cycle, quotas of reinstatement, maintenance and insurance of durable capital, depreciation quotas related to the bank loan, taxes, remuneration of human labor, compensation for intellectual work, interests on anticipation capital, durable capital and land value.

In the economic evaluation process for the determination of reinstatement quotas, a period equal to twenty years has been considered, coinciding with the time frame during which the PV incentives are granted. The annual insurance and maintenance costs of PV panels amounted to $1 \%$ of their total investment cost.

After calculating the farm profit, considered the aforementioned rapid diffusion of PV systems in Italy that exceeded the legislature's expectations, we wanted to determine the minimum price of incentive tariff starting from which the entrepreneur finds it convenient to realize the investment. In this way we evaluated the efficiency of Italian energy policy, assessing if the PV incentive was reasonable compared to the goal of Second Conto Energia. For this purpose, as well as in other studies [67-69], the breakeven point has been calculated, that is, the point where revenues are equal to costs.

The breakeven point has been determined through the following formula:

$$
V_{\mathrm{a}}+V_{\mathrm{e}}=K
$$

where $V_{\mathrm{a}}$ is the agricultural production value; $V_{\mathrm{e}}$ is the electricity production value; $K$ corresponds to total costs.

The electricity production value is given by sum of value of energy sold to the grid and the revenues deriving from the incentive tariff:

$$
V_{\mathrm{e}}=\mathrm{KWh} \cdot p_{\mathrm{e}}+\mathrm{KWh} \cdot p_{\mathrm{t}}
$$


where KWh is the average annual electricity generated by the PV system; $p_{\mathrm{e}}$ represents the electricity sale price; $p_{\mathrm{t}}$ is the tariff price. According to Equation (1), this means:

$$
V_{\mathrm{a}}+\mathrm{KWh} \cdot p_{\mathrm{e}}+\mathrm{KWh} \cdot p_{\mathrm{t}}=K
$$

According to Equation (3), the minimum tariff price can be calculated using the following expression:

$$
p_{\mathrm{t}}=\frac{K-V_{\mathrm{a}}-\mathrm{KWh} \cdot p_{\mathrm{e}}}{\mathrm{KWh}}
$$

In the Equation (4), the factors in the second member are constant (because they do not depend on tariff price) except the costs. These, in fact, decrease at the progressive reduction of the incentive tariff that affects on taxes and interests on the anticipation capital.

\section{Results}

The economic analysis of the case study showed a farm profit amounted to $€ 112,709.74$ (Table 3 ).

Table 3. Economic results of case study (average annual data referred to a 20 -years period).

\begin{tabular}{ccc}
\hline Items & Euro/year & $\mathbf{\%}$ \\
\hline Revenues (A) & $\mathbf{2 3 6 , 0 5 0 . 1 1}$ & $\mathbf{1 0 0 . 0}$ \\
Agricultural production & $18,174.00$ & 7.7 \\
Electricity sale & $41,738.72$ & 17.7 \\
PV incentives & $176,137.39$ & 74.6 \\
Costs (B) & $\mathbf{1 2 3 , 3 4 0 . 3 7}$ & $\mathbf{1 0 0 . 0}$ \\
Materials and services & $8,100.80$ & 6.6 \\
Quotas & $94,486.49$ & 76.6 \\
Taxes & $8,068.68$ & 6.5 \\
Human labor & $8,501.20$ & 6.9 \\
Intellectual work & 726.96 & 0.6 \\
Interests & $3,456.23$ & 2.8 \\
Profit (A-B) & $\mathbf{1 1 2 , 7 0 9 . 7 4}$ & \\
\hline
\end{tabular}

As regards farm revenues a value equal to $€ 236,050.11$ has been registered. This value is composed for the most part of electricity production revenues deriving from the PV panels, which represented $92.3 \%$ of the farm revenues, which registered a marginal incidence of agricultural activity $(7.7 \%$ of total revenues). Among electricity production revenues, the main item is represented by PV incentives with a value of $€ 176,137.39$, constituting $74.6 \%$ of total revenues, while electricity sales amounted to just $17.7 \%$. Data showed that the farm profitability, after the PV investment, is closely linked to public incentives granted by feed-in scheme. Farm costs amounted to $€ 123,340.37$ and the main item is represented by quotas that with a value of $€ 94,486.49$ constituted $76.6 \%$ of total costs.

This value is essentially due to the depreciation quota $(60.7 \%$ of total cost) aimed to pay off the bank loan necessary for the purchase and installation of PV panels, despite the fact the investor has obtained a low interest rate.

Among costs, the second item in relative terms is given by the remuneration of human labor, which accounted for $6.9 \%$ of total costs, followed by costs related to materials and services coming from 
outside the farm (6.6\%); both items are correlated exclusively to the management of farm crops. Taxes represented $6.5 \%$ of the total cost and are due mainly to the farm energy production. Interests and intellectual work, finally, overall accounted just for $3.4 \%$ of farm total costs.

As the economic analysis showed that the farm profit is due largely to the incentive tariff, as mentioned above, the minimum tariff price (according to Equation (4)) starting from which the farmer obtains a positive profit from the investment realization has been determined.

Data in Table 4 showed that in the case of Second Conto Energia the breakeven point between costs and revenues is obtained for a price of the incentive tariff equal to $0.148 € \cdot \mathrm{kWh}^{-1}$.

Table 4. Economic results according to incentive tariff (in euros).

\begin{tabular}{ccc}
\hline Incentive tariff & Costs & Revenues \\
\hline 0.125 & $121,676.94$ & $112,086.12$ \\
0.130 & $121,704.94$ & $114,173.05$ \\
0.135 & $121,732.94$ & $116,259.99$ \\
0.140 & $121,760.95$ & $118,346.92$ \\
0.145 & $121,788.95$ & $120,433.86$ \\
$\mathbf{0 . 1 4 8}$ & $\mathbf{1 2 1 , 8 0 7 . 3 8}$ & $\mathbf{1 2 1 , 8 0 7 . 3 8}$ \\
0.150 & $121,816.96$ & $122,520.80$ \\
0.155 & $121,844.96$ & $124,607.73$ \\
0.160 & $121,872.96$ & $126,694.67$ \\
0.165 & $121,900.97$ & $128,781.60$ \\
0.170 & $121,928.97$ & $130,868.54$ \\
\hline
\end{tabular}

If the incentive tariff corresponds to this value, farm costs and revenues are equal to a value of $€ 121,807.38$, obtaining a null profit and setting the intersection between revenues straight line and costs one (Figure 2).

Figure 2. Breakeven point determination.

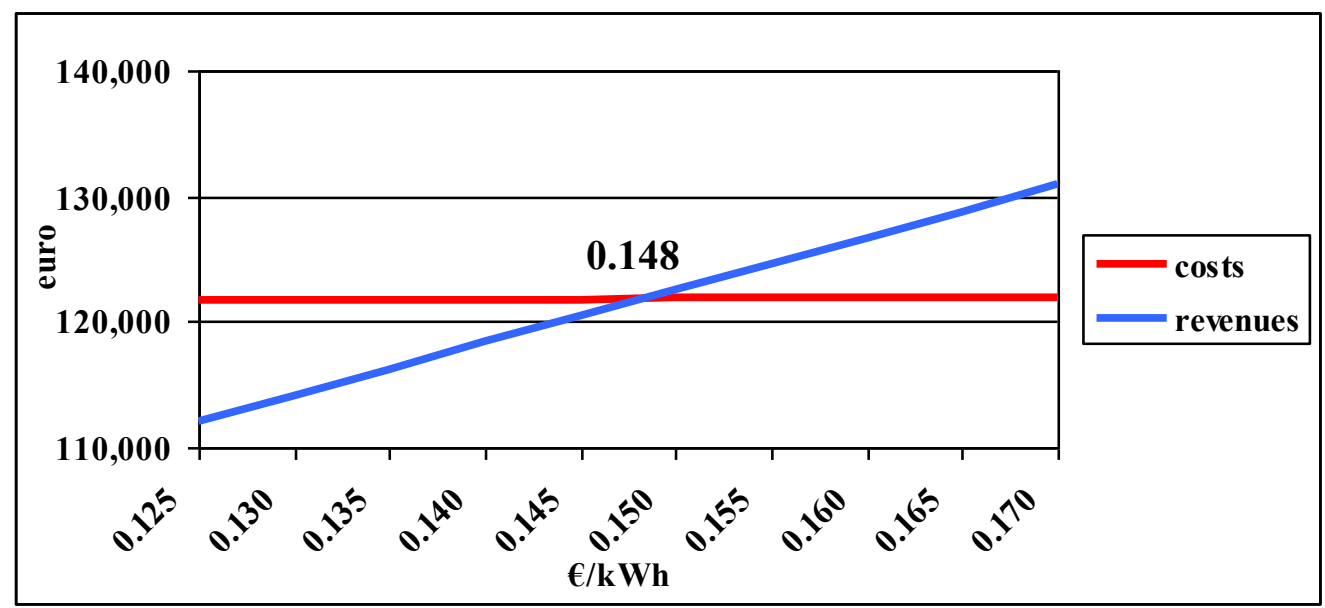

From the results it appears evident that the value of farm costs does not display substantial changes with varying tariffs. This is due to fact that tariff affects only the taxes and interest on the anticipation capital, but not the other cost items. In fact, according to Italian taxation, a withholding tax on PV incentives equal to $4 \%$ on the part in excess of $200 \mathrm{~kW}$ is provided [70]. 
Ultimately, under the minimum tariff price determined, the farmer would not have advantage to realize the investment, while with higher values he would obtain a positive profit. This highlights the high profitability of the PV system, which is ensured by an incentive tariff substantially higher, equal to $0.422 € \cdot \mathrm{kWh}^{-1}$. Therefore, the analyzed case study has shown that the incentive tariff goes far beyond the feed-in scheme targets, denoting an inefficiency of public spending for PV energy policy.

\section{Conclusions}

Over the last years Italian PV development has not seen significant interruptions after the entry into force of the Second Conto Energia, showing a high energy policy efficacy. This sudden and unexpected growth is mainly attributable both to the reduction of the PV installation costs and the high government incentives granted to entrepreneurs that, despite the financial crisis, have identified in the PV industry a sector with low risk and high profitability. This trend has also affected the agricultural sector, from which it derives $13 \%$ of installed capacity of Italian PV plants.

In this context, in order to evaluate the efficiency of Italian energy policy, firstly the profitability of a Sicilian farm that, during the Second Conto Energia, has installed PV panels on greenhouses has been determined. The high farm profitability, observed in the case study, is attributable to substantial revenues deriving from electricity sales and especially from the incentive tariff. These revenues represent the majority of farm revenues, relegating the agricultural activity to a marginal role.

Subsequently, the minimum incentive tariff starting from which the farmer has an economic advantage to realize the PV investment it has been determined. The economic convenience of PV investment analyzed is evident if it considers that the minimum incentive tariff starting from which the farmer obtains a positive profit (equal to $0.148 € \cdot \mathrm{kWh}^{-1}$ ) is far less than one granted by the Italian government $\left(0.422 € \cdot \mathrm{kWh}^{-1}\right)$.

Even if the surveyed case study does not entirely represent the Italian PV sector and it is not a decisive criterion for a full judgment about the Second Conto Energia, results are able to provide some economic considerations about the Italian energy policy. In fact, considering the goals of the Italian feed-in scheme, according to which the tariff had to ensure a fair remuneration for investment and operational costs, the results of this study show an inefficiency of public spending for PV energy policy. In particular, it has been noted that the PV investment was characterized by high government incentives that go far beyond the feed-in scheme targets [71-73].

The high values of these tariffs, in fact, have led the legislature to their continuous reshaping, with a succession within a few years of various feed-in schemes, reflecting a poor forecast of the evolution and potential related to PV sector. Moreover, the Italian Government has not anticipated such a fast and continuous reduction of PV panel prices, causing financial speculations and paying at great cost the growth of PV sector [74,75].

However, if on the one hand the PV energy policy has involved an inadequate public spending, since the same targets could have be achieved with a lower use of public funds, on the other hand it must be highlighted that it has reached and exceeded in a short time the legislature's objectives in terms of installed capacity, while also creating new job opportunities.

Ultimately it is hoped that future policies in terms of energy from renewable sources will favor self-consumption with suitable incentive tariffs aimed at creating in the territory a network of small 
energy producers. In this way on the one hand a radical transformation of the business core from agriculture to an energy production one should be avoided and on the other hand it should lead to lower public spending for the energy sector. This should be taken into account if we consider that the price of PV technologies is expected to decrease while the energy price is expected to increase in the future. In fact, the installation of PV systems should represent an activity aimed at supplementing farmers' income while reducing costs related to energy supply, especially for greenhouse specialized crops that entail high energy costs.

\section{Author Contributions}

This paper is a result of the full collaboration of all the authors. Salvatore Tudisca wrote the Conclusions, Anna Maria Di Trapani elaborated the section on Photovoltaic Remuneration Policies in Italy, Filippo Sgroi wrote the Results, Riccardo Testa elaborated the Case study and Methodology, while Riccardo Squatrito wrote the Introduction and Growth of PV Installed Capacity in Italy sections.

\section{Conflicts of Interest}

The authors declare no conflict of interest.

\section{References}

1. Tudisca, S.; Trapani, A.M.D.; Sgroi, F.; Testa, R.; Gianporcaro, G. Role of alternative food networks in sicilian farms. Int. J. Entrep. Small Bus. 2014, 22, 50-63.

2. Tudisca, S.; Trapani, A.M.D.; Donia, E.; Sgroi, F.; Testa, R. Entrepreneurial strategies of Etna wine farms. Int. J. Entrep. Small Bus. 2014, 21, 155-164.

3. Tudisca, S.; Trapani, A.M.D.; Sgroi, F.; Testa, R. Marketing strategies for Mediterranean wineries competitiveness: The case of Pantelleria. Qual. Access Success 2013, 14, 101-106.

4. Santeramo, F.G.; Di Pasquale, J.; Contò, F.; Tudisca, S.; Sgroi, F. Analyzing risk management in Mediterranean Countries: The Syrian perspective. New Medit 2012, 11, 35-40.

5. Tudisca, S.; Sgroi, F.; Testa, R. Competitiveness and sustainability of extreme viticulture in Pantelleria Island. New Medit 2011, 10, 57-64.

6. Ciorba, U.; Pauli, F.; Menna, P. Technical and economical analysis o fan induced demand in the photovoltaic sector. Energy Policy 2004, 32, 949-960.

7. Pearce, J.M. Photovoltaics-A path to sustainable futures. Futures 2002, 34, 663-674.

8. Karakosta, C.; Flouri, M.; Dimopoulou, S.; Psarras, J. Analysis of renewable energy progress in the western Balkan countries: Bosnia-Herzegovina and Serbia. Renew. Sustain. Energy Rev. 2012, 16, 5166-5175.

9. Chel, A.; Kaushik, G. Renewable energy for sustainable agriculture. Agron. Sustain. Dev. 2011, 31, 91-118.

10. Peng, J.; Lu, L.; Yang, H. Review on life cycle assessment of energy payback and greenhouse gas emission of solar photovoltaic systems. Renew. Sustain. Energy Rev. 2013, 1, 255-274.

11. Badcock, J.; Lenzen, M. Subsidies for electricity-generating technologies: A review. Energy Policy 2010, 38, 5038-5047. 
12. Szabó, S.; Jäger-Waldau, A.; Szabó, L. Risk adjusted financial costs of photovoltaics. Energy Policy 2010, 38, 3807-3838.

13. Bürer, M.J.; Wüstenhagen, R. Which renewable energy policy is a venture capitalist's best friend? Empirical evidence from a survey of international clean-tech investors. Energy Policy 2009, 37, 4997-5006.

14. Tudisca, S.; Trapani, A.M.D.; Sgroi, F.; Testa, R.; Squatrito, R. Economic analysis of PV systems on buildings in Sicilian farms. Renew. Sustain. Energy Rev. 2013, 28, 691-701.

15. EurObserv'ER. 12th EurObserv'ER Report: The State of Renewable Energies in Europe. Available online: http://www.energies-renouvelables.org/observ-er/stat_baro/barobilan/ barobilan12.pdf (accessed on 26 April 2014).

16. ANIE-GIFI. Costi e Benefici del Fotovoltaico. Available online: http://www.rinnovabili.it/ wp-content/uploads/2012/04/Costi-e-benefici-del-Fotovoltaico_ANIE-GIFI1.pdf (accessed on 26 April 2014). (In Italian)

17. European Parliament and Council of European Union. Directive 2009/28/EC. Available online: http://www.eur-lex.europa.eu/LexUriServ/LexUriServ.do?uri=OJ:L:2009:140:0016:0062:it:PDF (accessed on 29 April 2014).

18. Vieri, S. Agricoltura Settore Multifunzionale allo Sviluppo; Edagricole: Bologna, Italy, 2012. (In Italian)

19. Italian Government. Law no. 27/2012. Available online: http://www.gazzettaufficiale.it/atto/ serie_generale/caricaDettaglioAtto/originario?atto.dataPubblicazioneGazzetta=2012-03-24\&atto. codiceRedazionale $=012 \mathrm{G} 0049$ \&elenco30giorni=false (accessed on 28 April 2014). (In Italian)

20. Poncet, C.; Muller, M.M.; Brun, R.; Fatnassi, H. Photovoltaic greenhouses, non-sense or a real opportunity for the greenhouse systems? Acta Horticul. 2012, 927, 75-80.

21. Mekhilef, S.; Faramarzi, S.Z.; Saidur, R.; Salam, Z. The application of solar technologies for sustainable development of agricultural sector. Renew. Sustain. Energy Rev. 2013, 18, 583-594.

22. Asdrubali, F.; Cotana, F.; Messineo, A. On the Evaluation of solar greenhouse efficiency in building simulation during the heating period. Energies 2012, 5, 1864-1880.

23. Messineo, A.; Volpe, R.; Marvuglia, A. Ligno-cellulosic biomass exploitation for power generation: A case study in Sicily. Energy 2012, 45, 613-625.

24. Messineo, A.; Panno, D. Municipal waste management in Sicily: Practices and challenges. Waste Manag. 2008, 28, 1201-1208.

25. Schuetze, T. Integration of photovoltaics in buildings-support policies addressing technical and formal aspects. Energies 2013, 6, 2982-3001.

26. Jenkins, J.D. Political economy constraints on carbon pricing policies: What are implications for economic efficiency, environmental efficacy, and climate polity design? Energy Policy 2014, 69, 467-477.

27. Airoldi, G.; Brunetti, G.; Coda, V. Corso di Economia Aziendale; Il Mulino: Milano, Italy, 2005. (In Italian)

28. European Parliament and Council of European Union. Directive 2001/77/EC. Available online: http://www.eur-lex.europa.eu/LexUriServ/LexUriServ.do?uri=CELEX:32001L0077:IT:HTML (accessed on 29 April 2014). 
29. Italian Government. D.L. 29/12/2003 no. 387. Available online: http://www.normattiva.it/ uri-res/N2Ls?urn:nir:stato:decreto.legislativo:2003;387 (accessed on 29 April 2014). (In Italian)

30. Italian Government. D.M. 28/07/2005. Available online: http://www.gazzettaufficiale.it/atto/ serie_generale/caricaDettaglioAtto/originario?atto.dataPubblicazioneGazzetta=2005-08-05\&atto. codiceRedazionale=05A07837\&elenco30giorni=false (accessed on 21 April 2014). (In Italian)

31. Italian Government. D.M. 06/02/2006. Available online: http://www.gazzettaufficiale.it/atto/ serie_generale/caricaDettaglioAtto/originario?atto.dataPubblicazioneGazzetta=2006-02-15\&atto. codiceRedazionale=06A01351\&elenco30giorni=false (accessed on 21 April 2014). (In Italian)

32. Italian Government. D.M. 19/02/2007. Available online: http://www.gazzettaufficiale.it/atto/ serie_generale/caricaDettaglioAtto/originario?atto.dataPubblicazioneGazzetta=2007-02-23\&atto. codiceRedazionale $=07$ A01710\&elenco30giorni=false (accessed on 22 April 2014). (In Italian)

33. Italian Government. D.M. 06/08/2010. Available online: http://www.gazzettaufficiale.it/atto/ serie_generale/caricaDettaglioAtto/originario?atto.dataPubblicazioneGazzetta=2010-08-24\&atto. codiceRedazionale $=10$ A10236\&elenco30giorni=false (accessed on 24 April 2014). (In Italian)

34. Italian Government. Law no. 129/2010. Available online: http://www.gazzettaufficiale.it/atto/ serie_generale/caricaDettaglioAtto/originario?atto.dataPubblicazioneGazzetta $=2010-08-18 \&$ atto. codiceRedazionale $=010 \mathrm{G} 0161 \&$ elenco30giorni=false (accessed on 24 April 2014). (In Italian)

35. Italian Government. D.M. 05/05/2011. Available online: http://www.gazzettaufficiale.it/atto/ serie_generale/caricaDettaglioAtto/originario?atto.dataPubblicazioneGazzetta=2011-05-12\&atto. codiceRedazionale=11A06083\&elenco30giorni=false (accessed on 24 April 2014). (In Italian)

36. Couture, T.; Gagnon, Y. An analysis of feed-in tariff remuneration models: Implications for renewable energy investment. Energy Policy 2010, 38, 955-965.

37. Del Río, P. Ten years of renewable electricity policies in Spain: an analysis of successive feed-in tariff reforms. Energy Policy 2008, 36, 2917-2929.

38. Lesser, J.A.; Su, X. Design of an economically efficient feed-in tariff structure for renewable energy development. Energy Policy 2008, 36, 981-990.

39. EPIA. Solar Photovoltaics, Competiting in the Energy Sector, on the Road to Competitiveness. Available online: http://www.epia.org (accessed on 28 April 2014).

40. MSE. Piano di Azione Nazionale per le Energie Rinnovabili dell'Italia. Available online: http://www.sviluppoeconomico.gov.it/images/stories/recuperi/Notizie/Piano.pdf (accessed on 30 April 2014). (In Italian)

41. Lüthi, S. Effective deployment of photovoltaics in the Mediterranean countries: Balancing policy risk and return. Solar Energy 2010, 84, 1059-1071.

42. Italian Government. D.M. 05/07/2012. Available online: http://www.gazzettaufficiale.it/atto/ serie_generale/caricaDettaglioAtto/originario?atto.dataPubblicazioneGazzetta=2012-0710\&atto. codiceRedazionale=12A07629\&elenco30giorni=false (accessed on 24 April 2014). (In Italian)

43. GSE. Rapporto Statistico 2011 Solare Fotovoltaico. Available online: http://www.gse.it/it/ Dati\%20e\%20Bilanci/Osservatorio\%20statistico/Pages/default.aspx (accessed on 2 May 2014). (In Italian)

44. GSE. Risultati Incentivazione. Available online: http://www.gse.it/it/Conto $\% 20$ Energia/Risultati\% 20incentivazione/ Pages/default.aspx (accessed on 2 May 2014). (In Italian) 
45. Sarasa-Maestro, C.J.; Dufo-López, R.; Bernal-Agustín, J.L. Photovoltaic remuneration policies in the European Union. Energy Policy 2013, 55, 317-328.

46. ABI. Green Energy 2012: Nuova Energia alle Energie Rinnovabili. Available online: http://www.abi.it (accessed on 3 May 2014). (In Italian)

47. Ibanez, A.M.; Martinelli, F.; Uratsu, S.L.; Vo, A.; Tinoco, M.A.; Phu, M.L.; Chen, Y.; Rocke D.M.; Dandekar, A.M. Transcriptome and metabolome analysis of Citrus fruit to elucidate puffing disorder. Plant Sci. 2014, 217, 87-98.

48. D'Asaro, F.; Grillone, G. Empirical investigation of curve number method parameters in the Mediterranean area. J. Hydrol. Eng. 2012, 17, 1141-1152.

49. Agnese, C.; Grillone, G.; D’Asaro, F.; Drago, A. Comparison of temperature data collected in urban and agricultural areas surrounding. Ital. J. Agrometeorol. 2008, 13, 48-49.

50. Grillone, G.; Agnese, C.; D'Asaro, F. Estimation of solar radiation in Sicily by daily data maximum and minimum temperature. Ital. J. Agrometeorol. 2009, 14, 84-85.

51. Tudisca, S.; Trapani, A.M.D.; Sgroi, F.; Testa, R. Economic evaluation of PDO introduction in Sicilian orange farms. Qual. Access Success 2014, 15, 99-103.

52. Tudisca, S.; Trapani, A.M.D.; Sgroi, F.; Testa, R. Organic farming and economic sustainability: The case of Sicilian durum wheat. Qual. Access Success 2014, 15, 93-96.

53. García-Galán, M.M.; del Moral-Agúndez, A.; Galera-Casquet, C. Assessing the introduction and development of a designation of origin from the firm's perspective: The case of the Ribera del Guadiana wine PDO. Span. J. Agric. Res. 2012, 10, 890-900.

54. Kalogirou, S.A. Solar Energy Engineering: Processes and Systems; Academic Press: Waltham, MA, USA, 2009.

55. ENEA. L'energia Fotovoltaica. Available online: http://www.enea.it (accessed 3 May 2014). (In Italian)

56. Danchev, S.; Maniatis, G.; Tsakaniks, A. Returns on investment in electricity producing photovoltaic systems under de-escalating feed-in tariffs: The case of Greece. Renew. Sustain. Energy Rev. 2010, 14, 500-505.

57. Lasnier, F.; Ang, T.G. Photovoltaic Engineering Handbook; Adam Hilger: New York, NY, USA, 1990.

58. Prestamburgo, M.; Saccomandi, V. Economia agraria; Etaslibri: Milano, Italy, 1995. (In Italian)

59. Guerrieri, G.; Pennacchi, F.; Sediari, T. Istituzioni di Economia e Politica Agraria; Edagricole: Bologna, Italy, 1995. (In Italian)

60. Iacoponi, L.; Romiti, R. Economia e Politica Agraria; Edagricole: Bologna, Italy, 1994. (In Italian)

61. Daniele, C. Valutazione della convenienza economica del fotovoltaico in azienda agricola. Agriregioneuropa 2011, 24, 27-30. (In Italian)

62. Canali, M. La produzione di energia da impianti fotovoltaici nelle aziende agricole, costi e redditività. In Cambiamenti nel sistema alimentare-Nuovi problemi, strategie, politiche. In Proceedings of the XLVI Convegno Sidea, Piacenza, Italy, 16-19 September 2009; pp. 221-237. (In Italian)

63. Daniele, C.; Lombardi, G.V.; EI Asmar, T. Sistemi fotovoltaici in agricoltura: Un'analisi dell'investimento nel centro Italia. Riv. Econ. 2008, 63, 273-297. (In Italian) 
64. GSE. Ritiro Dedicato. Available online: http://www.gse.it/it/Ritiro\%20e\%20scambio/ Ritiro\%20dedicato/Pages/default.aspx (accessed on 30 May 2014). (In Italian)

65. Oliva, H.S.; MacGill, I.; Passey, R. Estimating the net societal value of distributed household PV systems. Solar Energy 2014, 100, 9-22.

66. Radhi, H. Trade-off between environmental and economic implications of PV systems integrated into the UAE residential sector. Renew. Sustain. Energy Rev. 2012, 16, 2468-2474.

67. Tudisca, S.; Trapani, A.M.D.; Sgroi, F.; Testa, R. The cost advantage of Sicilian wine farms. Am. J. Appl. Sci. 2013, 10, 1529-1536.

68. Laspidou, C.; Charisiou-Kalliantopoulos, V. Design and Techno-Economic analysis of a photovoltaic system installed on a house in xanthi, Greece. Fresenius Environ. Bull. 2012, 21, 2494-2498.

69. Pulkrábek, J.; Kavka, M.; Rataj, V.; Humpál, J.; Nozdrovický, L.; Trávníček, Z.; Pačuta, V. The assessment of the economic risks level of sugar beet growing for the farm economy. Agric. Econ. CZ 2012, 58, 41-48.

70. Agenzia Entrate. Circolare n. 32/E, 2009. Available online: http://www.agenziaentrate. gov.it/wps/wcm/connect/3d5c030047839e308f89cfe33c46800f/circolare+32e.pdf?MOD=AJPERES (accessed on 30 May 2014). (In Italian)

71. López Polo, A.; Haas, R. An international overview of promotion policies for grid-connected photovoltaic systems. Prog. Photovolt. Res. Appl. 2014, 22, 248-273.

72. Orioli, A.; Di Gangi, A. Load mismatch of grid-connected photovoltaic systems: Review of the effects and analysis in an urban context. Renew. Sustain. Energy Rev. 2013, 21, 13-28.

73. Cherrington, R.; Goodship, V.; Longfield, A.; Kirwan, K. The feed-in tariff in the UK: A case study focus on domestic photovoltaic systems. Renew. Energy 2013, 50, 421-426.

74. Spertino, F.; Di Leo, P.; Cocina, V. Economic analysis of investment in the rooftop photovoltaic systems: A long-term research in the two main markets. Renew. Sustain. Energy Rev. 2013, 28, 531-540.

75. Cellura, M.; Di Gangi, A.; Longo, S.; Orioli, A. Photovoltaic electricity scenario analysis in urban contests: An Italian case study. Renew. Sustain. Energy Rev. 2012, 16, 2041-2052.

(C) 2014 by the authors; licensee MDPI, Basel, Switzerland. This article is an open access article distributed under the terms and conditions of the Creative Commons Attribution license (http://creativecommons.org/licenses/by/3.0/). 